\title{
Binding of human plasminogen and high-molecular-mass kininogen by cell surface-exposed proteins of Candida parapsilosis*
}

\author{
Justyna Karkowska-Kuleta ${ }^{\bowtie}$, Dorota Zajac², Grazyna Bras², Oliwia Bochenska², \\ Maria Rapala-Kozik' and Andrzej Kozik²
}

1Department of Comparative Biochemistry and Bioanalytics, Faculty of Biochemistry, Biophysics and Biotechnology, Jagiellonian University in Krakow, Kraków, Poland; 'Department of Analytical Biochemistry, Faculty of Biochemistry, Biophysics and Biotechnology, Jagiellonian University in Krakow, Kraków, Poland

Pathogenic microbes can recruit to their cell surface human proteins that are components of important proteolytic cascades involved in coagulation, fibrinolysis and innate immune response. Once located at the bacterial or fungal surface, such deployed proteins might be utilized by pathogens to facilitate invasion and dissemination within the host organism by interfering with functionality of these systems or by exploiting specific activity of the bound enzymes. Aim of the study presented here was to characterize this phenomenon in Candida parapsilosis (Ashford) Langeron et Talice - an important causative agent of systemic fungal infections (candidiases and candidemias) in humans. We have investigated the interactions of fungal surface-exposed proteins with plasminogen (HPG) and high-molecularmass kininogen (HK) - the crucial components of human fibrinolytic system and proinflammatory/procoagulant contact-activated kinin-forming system, respectively. After confirming ability of the fungal surface-exposed proteins to bind HPG and HK, four of them - two agglutinin-like sequence (Als) proteins CPAR2_404780 and CPAR2 404800, a heat shock protein Ssa2 and a moonlighting protein 6-phosphogluconate dehydrogenase 1 - were purified using ion-exchange chromatography, gel filtration and chromatofocusing. Then, their affinities to HPG and HK were characterized with surface plasmon resonance measurements. The determined dissociation constants for the investigated protein-protein complexes were within a 10-7 $\mathrm{M}$ order for the HPG binding and in a range of $10^{-8}-10^{-9} \mathrm{M}$ for the HK binding. Detailed characterization of adsorption of these two important plasma proteins on the fungal cell surface may help to increase our understanding of molecular mechanisms of $C$. parapsilosis-dependent candidiasis.

Key words: candidiasis, cell wall proteins, fibrinolysis, contact system Received: 19 March, 2017; revised: 04 May, 2017; accepted: 10 May, 2017; available on-line: 24 June, 2017

\section{e-mail: justyna.karkowska@uj.edu.pl}

${ }^{*}$ A preliminary report on this subject was presented at the 44th Winter School of the Faculty of Biochemistry, Biophysics and Biotechnology of Jagiellonian University in Krakow, "No stress - no life", Zakopane, Poland, 14-18 February 2017.

Abbreviations: Als, agglutinin-like sequence; BSA, bovine serum albumin; GPI, glycosylphosphatidylinositol; HK, high-molecular-mass kininogen; HPG, human plasminogen; Hyr, hyphally regulated protein; LC-MS/MS, liquid chromatography-coupled tandem mass spectrometry; PBS, phosphate buffered saline; RU, resonance units; SDS-PAGE, sodium dodecyl sulfate polyacrylamide gel electrophoresis

\section{INTRODUCTION}

The development of infections caused by pathogenic microorganisms affects the action of major systems involved in maintaining the biochemical homeostasis of the human organism. This phenomenon is related to both, triggering of the host immune responses and engagement and activation of the pathogens' virulence factors. To efficiently disseminate with the bloodstream, colonize new niches of the human body and to successfully evade the host immune system, microorganisms can take control over several plasma proteolytic cascades involved in the coagulation and subsequent degradation of fibrin clots, or in the development of the inflammatory state during infection (Sun, 2006; Shannon et al., 2013).

Secreted or surface-located microbial proteases often possess an ability to activate or inactivate particular enzymatic components of these proteolytic cascades or to degrade dedicated proteinase inhibitors, thus leading to deregulation of the physiological functionality of such systems (Maeda \& Yamamoto, 1996; Potempa et al., 2000; Kozik et al., 2015a; Gogol et al., 2016; Huish et al., 2017). Moreover, a great variety of bacterial or fungal surface-exposed proteins were repeatedly reported to be involved in the interactions with human plasma proteins (Smeesters et al., 2010; Rapala-Kozik et al., 2011; Wollein Waldetoft et al., 2012; Castiblanco-Valencia et al., 2016).

Gathering the components of plasma kinin-generating system ("contact system") - prekallikrein (pHPK), coagulation factor XII (FXII) and high-molecular-mass kininogen $(\mathrm{HK})$ - at the microbial cell surface can result in this system's activation. This might be related not only to the final formation of fibrin clots or to the complement activation, but, most importantly, also to the release from HK biologically active peptides - kinins that are potent proinflammatory mediators responsible for increase in the vascular permeability and vasodilatation (Holm et al., 2011; Long et al., 2016; Vieira et al., 2016). Although activation of the contact system is one of the mechanisms contributing to the mobilization of human defense against pathogens, the increased inflow of plasma to the site of infection greatly facilitates microbial dissemination and helps them to acquire nutrients, thereby becoming a beneficial phenomenon for invading bacteria and fungi (Frick et al., 2007; Nickel \& Renné, 2012).

Additionally, capturing a key component of fibrinolytic system - plasminogen (HPG) - by the surface-associated proteins allows microorganisms to utilize its zymogen 
activity. After conversion of plasminogen to plasmin, the latter surface-bound active proteinase can be employed to hydrolyze a fibrin clot, in which the pathogens are entrapped, or to degrade extracellular matrix proteins and penetrate the surrounding tissues (Herwald et al., 2003; Loof et al., 2014).

In addition to many reports concerning the binding of human HPG and HK by the cell wall proteins of the most important fungal human pathogen, Candida albicans (Robin) Berkhout (Crowe et al., 2003; Karkowska-Kuleta et al., 2011; Marín et al., 2015), still relatively little is known about this phenomenon in other emerging pathogens from the Candida genus - the so-called "non-albicans" Candida species. One of them is C. parapsilosis (Ashford) Langeron et Talice, which has been recognized as a commensal strain widely distributed in the environment and colonizing human skin and nails (Bonassoli et al., 2005; Yang et al., 2011); however, currently C. parapsilosis is frequently reported to be the third or even the second, right after $C$. albicans, causative agent of invasive candidiases in humans (Trofa et al., 2008; Pfaller et al., 2014; Fathi et al., 2016; Y1lmaz et al., 2016). C. parapsilosis is often isolated from hands of the health personnel and from environmental surfaces in hospitals (Sanchez et al., 1993; Sabino et al., 2011). Furthermore, it possesses a great ability to adhere to and form biofilms on the surface of implanted medical devices (Diekema et al., 1997; Pongrácz et al., 2016). Therefore, this species is often responsible for serious nosocomial infections, including life-threatening candidemia and infectious endocarditis, diagnosed predominantly in immunocompromised individuals and among critically ill neonates (Garzoni et al., 2007; Juyal et al., 2013; Lovero et al., 2016). In the case of premature infants and newborns with birth weight lower than $1500 \mathrm{~g}$, the mortality rates of about $10 \%$ related to invasive infections caused by C. parapsilosis have now become an emerging problem (Benjamin et al., 2006). One of the important factors that is conducive to such infections is the presence of C. parapsilosis on the skin that facilitates horizontal transmissions of the fungus in hospitals (Lupetti et al., 2002). Another important problem is a significant predisposition of this species to adhere to vascular catheters used for parenteral nutrition of neonates, which is often followed by formation of biofilm and further development of disseminated infection and antifungal drug resistance (Chow et al., 2012). Expanding the knowledge on C. parapsilosis virulence factors, especially in terms of fungal adhesion to host proteins and cells may be very helpful to prevent such infections in the future (Pammi et al., 2013).

In the $C$. parapsilosis genome many gene families have been annotated as encoding proteins likely to be located within the fungal cell wall - an important part of the cell that participates in ceaseless and interactive contact with the host during infection. Examples include families of predicted proteins equipped with glycosylphosphatidylinositol (GPI) anchors, such as chitinases, Ecm33like proteins, Sod-like (superoxide dismutase) proteins, yapsins, Hwp-like (hyphal wall protein) proteins, Rbt-like (repressed by TUP1) proteins, Pga24/59/62- and Pga30like (predicted GPI-anchored) proteins, as well as large families of Als-like (agglutinin-like sequence) and $\mathrm{Hyr} /$ Iff-like (hyphally regulated) proteins, and others (Butler et al., 2009). Moreover, a number of proteins without predicted GPI anchor are present at the cell surface of C. parapsilosis cells, as indicated by the results obtained with the method of cell surface shaving with trypsin (Karkowska-Kuleta et al., 2015), including heat shock protein Ssa2, enolase, phosphoglycerate mutase and al- cohol dehydrogenase. Proteins representing both groups have been shown recently to play an important role in adhesion of $C$. parapsilosis cells to biotic and abiotic surfaces. Bertini et al. (2016) demonstrated involvement of the C. parapsilosis Als-like protein CPAR2_404800 in interactions with human epithelial cells, whereas NúñezBeltrán et al. (2017) confirmed the contribution of surface-localized phosphoglycerate kinase and enolase in adherence of the C. parapsilosis cells to silicone implants.

Since sequestration of the host plasma proteins at the pathogen cell surface might be an efficient mechanism contributing to increased pathogenicity of Candida spp. (Jong et al., 2003; Rapala-Kozik et al., 2008; Karkowska-Kuleta et al., 2010; Funk et al., 2016), our current work aimed at a detailed characterization of the interactions between human plasma proteins important for maintaining the hemostatic balance and the development of inflammation - HPG and HK - and selected fungal proteins known to be present at the $C$. parapsilosis cell surface. A subset of $C$. parapsilosis cell wall proteins potentially capable of interacting with HPG and HK was first identified using an affinity chromatography on agarose gels coupled with these human proteins. Then, the whole mixture of native cell wall proteins was subjected to protein purification procedures, searching for the pre-assumed HPG- and HK-binding candidates in the chromatographic fractions. Four confirmed HPGand HK-binding proteins were finally isolated and purified, including two GPI-anchored putative adhesins from the Als-like protein family (CPAR2_404800 and CPAR2_404780) and two cell surface proteins that are not equipped with GPI-anchor but for which there is evidence for involvement in interactions with the host proteins and peptides - heat shock protein Ssa2 (Sun et al., 2008) and 6-phosphogluconate dehydrogenase (Gnd1) (Karkowska-Kuleta et al., 2011). The interactions of these proteins with HPG and HK were then characterized with the use of surface plasmon resonance (SPR) measurements.

\section{MATERIALS AND METHODS}

Proteins. Human plasma HK was purchased from Enzyme Research Laboratories (South Bend, IN, USA). Human plasma HPG and $\beta-1,3$-glucanase were from Sigma (St. Louis, MO, USA), $\beta-1,6$-glucanase from Takara Bio Inc. (Otsu, Shiga, Japan) and trypsin was from Promega (Madison, WI, USA). Bovine serum albumin (BSA) was obtained from BioShop Canada Inc (Burlington, Ontario, Canada) and the horseradish peroxidase-conjugated streptavidin solution (SA-HRP) from MP Biomedicals (Solon, OH, USA). Biotin-labeled HPG (HPG-Bt) and $\mathrm{HK}(\mathrm{HK}-\mathrm{Bt})$ were obtained using biotin N-hydroxysuccinimide ester (Sigma) and a procedure described previously (Rapala-Kozik et al., 2008).

Yeast strain and culture conditions. C. parapsilosis strain CDC 317 (ATCC ${ }^{\circledR}$ MYA-4646 ${ }^{\mathrm{TM}}$ ) was purchased from American Type Culture Collection (Manassas, VA, USA). Fungal pseudohyphal forms were obtained after inoculating of yeast forms that were previously grown to the stationary phase for 16 hours at $30^{\circ} \mathrm{C}$ in YPD medium (1\% yeast extract, $2 \%$ soybean peptone and $2 \%$ glucose) (Sigma), to RPMI 1640 medium (PAA Laboratories $\mathrm{GmbH}$, Pasching, Austria) and further culturing for 24 hours at $37^{\circ} \mathrm{C}$ in the wells of microtiter plates without shaking or for 72 hours at $37^{\circ} \mathrm{C}$ in flasks on an orbital rotary shaker MaxQ 4000 (Thermo Fisher Scientific, Waltham, MA, USA). 
Competition between HPG and HK for binding to the cell surface of $C$. parapsilosis pseudohyphae. The competition assay was performed on MaxiSorp 96well microtiter plates (Nunc, Roskilde, Denmark) where $1 \times 10^{6}$ of $C$. parapsilosis cells were grown in $150 \mu \mathrm{l}$ of RPMI 1640 medium for 24 hours. After each stage of the assay, the cells were gently washed three times with $200 \mu$ l of phosphate buffered saline (PBS), pH 7.4, additionally containing $1 \%$ BSA. The unoccupied well surface was blocked for 1 hour at $37^{\circ} \mathrm{C}$ with $300 \mu \mathrm{l}$ of $3 \%$ BSA in PBS. Then, $40 \mu \mathrm{l}$ of $50 \mathrm{nM}$ HPG-Bt or HK-Bt solution were added to the wells together with $10 \mu \mathrm{l}$ of a competitor solution - unlabeled HK or HPG, respectively - used at a variable molar excess (the final concentrations were within a range of $50-800 \mathrm{nM}$ ). After incubation for 1.5 hours at $37^{\circ} \mathrm{C}$, the bound labeled protein was detected with a solution of horseradish peroxidaseconjugated streptavidin (SA-HRP) and the substrate for HRP, 3,3'5,5' tetramethylbenzidine (TMB) (Sigma) as described previously (Rapala-Kozik et al., 2008).

Binding of biotinylated HPG and HK to the surface of $C$. parapsilosis pseudohyphae pretreated with $\beta$-1,3-glucanase, $\beta$-1,6-glucanase, heat or trypsin. HPG- and HK-binding capacities of fungal cells after treatment with $\beta$-1,3-glucanase and $\beta$-1,6-glucanase were tested with the use of pseudohyphal forms of C. parapsilosis pretreated with both enzymes separately. $\beta-1,3-$ and $\beta-1,6$-glucanase release cell wall proteins covalently attached to glucans by hydrolyzing the glucan network in which the surface proteins are embedded, but the latter enzyme does it without destroying the $\beta$-1,3-glucan layer of the cell wall (Kapteyn et al., 2000). Moreover, in an additional approach, the cell wall-associated proteins were also removed by trypsin hydrolysis and such cells were also subjected to further binding analysis. C. parapsilosis cells $\left(5 \times 10^{8}\right)$ were incubated in Eppendorf tubes for 1.5 hours at $37^{\circ} \mathrm{C}$ with: (i) $100 \mathrm{U}$ of $\beta-1,3$-glucanase


$\beta$-1,6-glucanase in $100 \mu \mathrm{l}$ of McIlvaine buffer ( $\mathrm{pH}$ 6.0), or (iii) $10 \mathrm{U}$ of trypsin in $100 \mu \mathrm{l}$ of $25 \mathrm{mM}$ ammonium bicarbonate buffer ( $\mathrm{pH}$ 8.0). Separate portions of cells suspended in $100 \mu \mathrm{l}$ of PBS were heated at $80^{\circ} \mathrm{C}$ for 30 minutes and then cooled. Next, the fungal cells were washed three times with $1 \mathrm{ml}$ of PBS and incubated with $100 \mu \mathrm{l}$ of $50 \mathrm{nM}$ solution of HPG-Bt or HK-Bt in PBS for 1.5 hours at $37^{\circ} \mathrm{C}$. The amount of bound biotinylated protein was determined with the SA-HRP/TMB detection system after transferring cells to new Eppendorf tubes and extensive washing out of unbound proteins.

Affinity chromatographic identification of HPGand HK-binding $C$. parapsilosis proteins. The method described previously (Karkowska-Kuleta et al., 2011) was followed with some modifications. Briefly, Affi Gel10 (Bio-Rad, Herkules, CA, USA) containing covalently coupled HPG or HK (500 $\mu \mathrm{g}$ per $1 \mathrm{ml}$ of gel) was incubated with the whole mixture of $C$. parapsilosis cell wall proteins isolated with $\beta-1,6$-glucanase. After washing out of the unbound proteins, the adsorbed putative HPG- and HK-binding proteins were eluted by boiling the gel in SDS. The isolated proteins were separated by sodium dodecyl sulfate polyacrylamide gel electrophoresis (SDS-PAGE) in the Laemmli system (Laemmli, 1970) and stained with Coomassie Brilliant Blue R-250. The proteins were then identified with liquid chromatography-coupled tandem mass spectrometry (LC-MS/MS) (see below).

Purification of heat shock protein Ssa2, 6-phosphogluconate dehydrogenase 1 (Gnd1) and agglutinin-like sequence proteins, CPAR2_404780 and
CPAR2_404800, from the whole mixture of proteins isolated from $C$. parapsilosis cell wall with $\beta-1,6-$ glucanase. C. parapsilosis pseudohyphae obtained after growth in RPMI 1640 medium for 72 hours at $37^{\circ} \mathrm{C}$ were centrifuged and washed three times with $1 \mathrm{ml}$ of PBS. Then, the fungal cells ( $0.4 \mathrm{~g}$ of wet weight) were incubated for 24 hours at $37^{\circ} \mathrm{C}$ in $1 \mathrm{ml}$ of McIlvaine buffer, pH 6.0 with $2 \mathrm{U}$ of $\beta-1,6$-glucanase. Next, the supernatant was collected and dialyzed against $20 \mathrm{mM}$ Tris- $\mathrm{HCl}$ buffer, $\mathrm{pH} 8.0$ for 48 hours at $4^{\circ} \mathrm{C}$. The integrity of cell membrane was tested with Trypan Blue (Sigma) staining. The quality of the obtained protein extracts was tested with SDS-PAGE in the Laemmli system and the protein concentration was assessed with the Bradford method (Bradford, 1976).

To purify selected $C$. parapsilosis surface-exposed proteins, the purification strategy similar to that described previously for C. tropicalis (Castellani) Berkhout cell wall proteins (Karkowska-Kuleta et al., 2016) was applied. During the first step of the purification procedure - ionexchange chromatography on Resource ${ }^{\mathrm{TM}} \mathrm{Q}$ column (GE Healthcare, Uppsala, Sweden) - we searched for fractions that on SDS-PAGE showed strong major band(s) which were found by LC-MS/MS to contain one of the candidate proteins, belonging to pre-identified (by affinity chromatography on immobilized HPG or HK, see above) subsets of putative HPG- or HK-binding cell wall proteins. Only those fractions were subjected to the next purification step - gel filtration on Superdex 200 HR column (GE Healthcare/Amersham Biosciences, Little Chalfont, UK). However, for the purification of Gnd1 and Ssa2, chromatofocusing was additionally used after gel filtration. For that step, the Ssa2- and Gnd1containing fractions after gel filtration were dialyzed against $25 \mathrm{mM}$ Bis-Tris-iminodiacetic acid buffer, $\mathrm{pH}$ 7.1, for 48 hours and then applied to a MonoP HR 5/20 column (GE Healthcare) pre-equilibrated with the same buffer. In order to elute proteins, a $20 \mathrm{ml}$ linear gradient of $10 \%$ Polybuffer 74 in $20 \mathrm{mM}$ Bis-Tris-iminodiacetic acid buffer $\mathrm{pH} 7.1$ (Sigma) was used at a flow rate of $0.5 \mathrm{ml} / \mathrm{min}$ (Bras et al., 2013). The effluent absorbance at $280 \mathrm{~nm}$ was continuously monitored and $\mathrm{pH}$ of the eluted fractions was checked with laboratory $\mathrm{pH}$-meter every three minutes during the separation to ensure the linearity of the $\mathrm{pH}$ gradient. After observing an increase in the absorbance, the fractions containing proteins with isoelectric point $(\mathrm{pI})$ values close to 5.0 and 6.0 were collected and then individually applied to the Superdex $200 \mathrm{HR} 10 / 50$ column in the $20 \mathrm{mM}$ Tris- $\mathrm{HCl} \mathrm{pH} 6.7$ at a flow rate of $0.5 \mathrm{ml} / \mathrm{min}$ in order to separate proteins from ampholytes. After each purification step, the selected fractions were characterized by SDS-PAGE and particular proteins were identified with LC-MS/MS, as described in detail below.

Protein identification with LC-MS/MS. To identify the content of the protein bands on the electrophoretic gels, the previously published protocol was used (Seweryn et al., 2015), with minor modifications. Briefly, the bands were manually excised and destained by an extensive washing with $100 \mu \mathrm{l}$ of $50 \%$ acetonitrile (ACN) and $25 \% \mathrm{ACN}$ in $25 \mathrm{mM}$ ammonium bicarbonate $\mathrm{NH}_{4} \mathrm{H}$ $\mathrm{CO}_{3}$ ). After that, they were subjected to reduction with $100 \mu \mathrm{l}$ of $10 \mathrm{mM}$ dithiothreitol in $25 \mathrm{mM} \mathrm{NH} \mathrm{NCO}_{3}$ at $37^{\circ} \mathrm{C}$ for 45 minutes and then alkylation with $100 \mu \mathrm{l}^{3}$ of $50 \mathrm{mM}$ iodoacetamide in $25 \mathrm{mM} \mathrm{NH}_{4} \mathrm{HCO}_{3}$ for 1.5 hours at room temperature in the dark. The excess reagents were washed out with $200 \mu \mathrm{l}$ of $50 \% \mathrm{ACN}$ in $25 \mathrm{mM} \mathrm{NH}_{4} \mathrm{HCO}_{3}$ and protein bands were treated with $50 \mu \mathrm{l}$ of $100 \% \mathrm{ACN}$ and then air-dried. In the next 
step, the proteins were treated with $15 \mu \mathrm{l}$ of trypsin $\left(0.1 \mu \mathrm{g} / 10 \mu \mathrm{l}\right.$ in $\left.25 \mathrm{mM} \mathrm{NH} \mathrm{HCO}_{3}\right)$ overnight at $37^{\circ} \mathrm{C}$. The peptides were extracted with $50 \mu \mathrm{l}$ of $50 \% \mathrm{ACN}$ and $0.5 \%$ formic acid and dried in an Alpha 1-2 lyophilizer (Christ, Osterode, Germany). After dissolution in $35 \mu \mathrm{l}$ of $10 \% \mathrm{ACN}$ with $0.1 \%$ formic acid, the obtained peptides were separated and analyzed by the LC-MS/ MS technique carried out with an HCT Ultra ion-trap mass spectrometer equipped with an electrospray ionization ion source and an electron-transfer dissociation II fragmentation module (Bruker, Bremen, Germany) and coupled to an ultrahigh-performance liquid chromatography Dionex Ultimate 3000 system (Carlsbad, CA, USA). The protein identification was performed through the National Center for Biotechnology Information (NCBI) protein database search with an in-house Mascot server (v.3.0, Matrix Science, London, UK).

Binding of HPG-Bt or HK-Bt to C. parapsilosis pseudohyphae in the presence of purified CPAR2_404780, CPAR2_404800, Ssa2 and Gnd1. C. parapsilosis pseudohyphae were obtained after growth of $1 \times 10^{6}$ cells in RPMI 1640 medium in the wells of MaxiSorp microtiter plates for 24 hours at $37^{\circ} \mathrm{C}$. After each step of the competition assay, the cells were washed with $300 \mu \mathrm{l}$ of PBS with $1 \%$ BSA. The unoccupied well surface was blocked for 1 hour at $37^{\circ} \mathrm{C}$ with $300 \mu$ l of $3 \%$ BSA in PBS. Then, $40 \mu \mathrm{l}$ of the HPG-Bt or HK$\mathrm{Bt}(50 \mathrm{nM})$ solutions, prepared in PBS, were added to the wells together with $10 \mu \mathrm{l}$ of the $1.2 \mu \mathrm{M}$ solutions of a particular purified fungal protein, CPAR2_404780, CPAR2_404800, Ssa2 or Gnd1 (final concentration: 240 $\mathrm{nM}$ ), also prepared in PBS, and gently mixed. After incubation for 1.5 hours at $37^{\circ} \mathrm{C}$ and washing out of the unbound proteins, the amount of bound biotinylated protein was detected with SA-HRP/TMB detection system.

Characterization of binding of $C$. parapsilosis proteins to HPG and HK with SPR measurements. The kinetic and thermodynamic analyses of binding of CPAR2_404780, CPAR2_404800, Ssa2 and Gnd1 to HPG or HK were carried out with a BIACORE 3000 system (GE Healthcare). For those measurements, the fungal protein was immobilized onto a surface of CM5 via amine groups and the solutions of human proteins, used at a sufficiently wide range of concentrations, flowed over this surface. In detail, the fungal proteins were dialyzed against $10 \mathrm{mM}$ HEPES buffer, $150 \mathrm{mM}$ $\mathrm{NaCl}, \mathrm{pH} 7.4$ and immobilized onto a CM5 sensor chips with the use of the Amine Coupling Kit (GE Healthcare). The surface of sensor chip was first activated by injection of $50 \mathrm{mM}$ 1-ethyl-3-(3-dimethylaminopropyl) carbodiimide (EDC) and $200 \mathrm{mM}$ N-hydroxysuccinimide (NHS), then the particular protein of interest was injected over the chip surface with a flow rate of $10 \mu \mathrm{l} / \mathrm{min}$ for 7 minutes. The immobilization was carried out in 10 $\mathrm{mM}$ sodium acetate buffer, $\mathrm{pH} 4.0$ for CPAR2_404780 and CPAR2_404800, $\mathrm{pH} 4.5$ for $\mathrm{Ssa} 2$ and $\mathrm{pH} 5.0$ for Gnd1, and the obtained immobilization level was 300 resonance units (RU) for CPAR2_404780, 310 for CPAR2_404800, 430 for Ssa2 and 300 for Gnd1. Next, the solutions of HPG or HK in $10 \mathrm{mM}$ HEPES buffer with $150 \mathrm{mM} \mathrm{NaCl}$ and $0.005 \%$ surfactant P20, which was also used as the running buffer, were injected at a flow rate of $30 \mu \mathrm{l} / \mathrm{min}$ at $25^{\circ} \mathrm{C}$. The association and dissociation time was 120 seconds and the regeneration of chip surface was carried out with a single injection of $1 \mathrm{M} \mathrm{NaCl}$ at a flow rate of $30 \mu \mathrm{l} / \mathrm{min}$ for 30 seconds. The obtained results were analyzed with a BIAevaluation 4.1 software (GE Healthcare). The dissociation and association rate constants $\left(k_{\mathrm{d}}\right.$ and $\left.k_{\mathrm{a}}\right)$ and the equilibrium dis- sociation constants $\left(K_{\mathrm{D}}\right)$ were calculated with the global fit of a simple (1:1) Langmuir model with a baseline drift to the complete set of obtained sensograms.

Statistical analysis. The data presented as the displacement plots were fitted using GraphPad Prism software with the nonlinear-regression one-phase exponential decay, and the particular data points are reported as the mean \pm standard deviation (S.D.). All results presented as the graph bars correspond to means \pm S.D. and after performing the Student's $t$-test it was assumed that the differences between values were statistically significant when $p<0.05$. The kinetic and thermodynamic binding parameters included in Table 2 and determined after global fitting analysis with the use of BIAevaluation 4.1 software, are presented with the standard errors (S.E.) of the obtained values.

\section{RESULTS}

The involvement of C. parapsilosis surface-exposed proteins in the fungal pseudohyphae interactions with human HPG and HK

It was confirmed that both investigated human plasma proteins - HPG and HK - could bind to the cell surface of C. parapsilosis pseudohyphae. Moreover, the displacement plots presented in Fig. 1 show that some binding sites located on the fungal cell wall might be shared in common by these two human proteins. When biotinylated HK competed with twenty-fold molar excess of non-biotinylated HPG for binding to C. parapsilosis cells grown in the wells of MaxiSorp microplate, its binding level decreased only by about $20 \%$. In an opposite situation, when HPG-Bt competed with HK added at the same molar excess, about $40 \%$ of the initial level of binding was retained. This result suggested a higher binding level for HK than for HPG.

The treatment of $C$. parapsilosis pseudohyphae with $\beta-1,3-$ glucanase or $\beta$-1,6-glucanase, resulting in the release of the substantial part of cell wall-associated proteins (Kapteyn et al., 1995; Rapala-Kozik et al., 2008; Karkowska-Kuleta \& Kozik, 2015) led to a decrease in the binding level of both, $\mathrm{HPG}$ and $\mathrm{HK}$, to approximately $20-25 \%$ in comparison



Figure 1. The displacement plots for competition between biotinylated HPG $(\boldsymbol{\Delta})$ or HK (ם) and an unlabeled respective protein for binding to $C$. parapsilosis pseudohyphae.

Pseudohyphal forms $\left(1 \times 10^{6}\right)$ of C. parapsilosis grown in the wells of Maxisorp microplate were incubated with the mixture of $40 \mu \mathrm{l}$ of $50 \mathrm{nM}$ HPG-Bt or HK-Bt prepared in PBS (the final concentration was $40 \mathrm{nM}$ ) and $10 \mu \mathrm{l}$ of HK or HPG as a competitor added in the final concentration range of $50-800 \mathrm{nM}$. After incubation at $37^{\circ} \mathrm{C}$ for 1.5 hours, the amount of bound biotinylated protein was determined with SA-HRP/TMB detection system. The displacement plots represent data fits with the nonlinear-regression for one phase exponential decay, obtained with the use of GraphPad Prism software for data points reported as the mean \pm standard deviation (S.D.). 


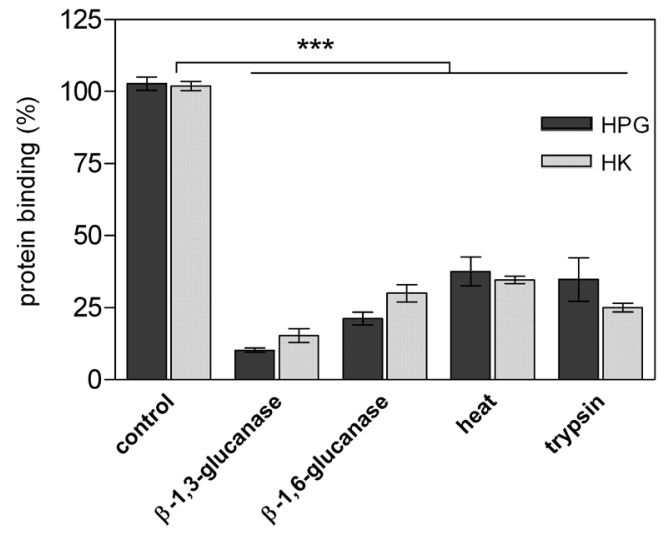

Figure 2. Binding of HPG-Bt and HK-Bt to the C. parapsilosis pseudohyphal forms that were treated with $\beta-1,3$-glucanase, $\beta$-1,6-glucanase, heat, and trypsin.

C. parapsilosis pseudohyphae $\left(5 \times 10^{8}\right)$ were incubated for 1.5 hours at $37^{\circ} \mathrm{C}$ with $\beta$-1,3-glucanase $(100 \mathrm{U}$ in $100 \mu \mathrm{l}), \beta-1,6$-glucanase $(0.2 \mathrm{U}$ in $100 \mu \mathrm{l})$, trypsin $(10 \mathrm{U}$ in $100 \mu \mathrm{l})$ or were heated at $80^{\circ} \mathrm{C}$ for 30 minutes in $100 \mu \mathrm{l}$ of PBS. Non-treated cells in PBS acted as a control of $100 \%$ binding. Then, $50 \mathrm{nM}$ solution of HPG-Bt or HKBt prepared in $100 \mu \mathrm{l}$ of PBS was incubated with fungal cells for 1.5 hours at $37^{\circ} \mathrm{C}$. After washing out the unbound proteins, the bound HPG-Bt or HK-Bt was detected with the SA-HRP/TMB system. The results are presented as the mean \pm standard deviation of three independent determinations. The statistical significance for each protein between values obtained for non-treated and treated cells was determined after performing the Student $t$-test and indicated as ${ }^{* * *}$ for $p<0.001$.

Table 1. Mass spectrometric identification of HPG-binding C. parapsilosis cell wall proteins.

$\beta$-1,6-glucanase was used for extraction of C. parapsilosis proteins. Particular HPG-binders were isolated with affinity chromatography and specific protein bands were excised after SDS-PAGE electrophoresis and digested using trypsin. Peptides were analyzed using the Dionex Ultimate 3000 ultrahigh-performance liquid chromatography system coupled to an HCT Ultra ETDII mass spectrometer equipped with an electrospray ionization ion source. The obtained lists of peaks were searched against the NCBI protein database (SC - sequence coverage).

\begin{tabular}{|c|c|c|c|c|c|c|}
\hline Accession & Protein & $\begin{array}{l}\text { Molecular } \\
\text { mass } \\
{[\mathrm{kDa}]}\end{array}$ & $\mathrm{pl}$ & Scores & $\begin{array}{l}\text { Number of } \\
\text { peptides }\end{array}$ & $\begin{array}{l}\mathrm{SC} \\
{[\%]}\end{array}$ \\
\hline gi|354544475 & $\begin{array}{l}\text { hypothetical protein CPAR2_301880, amidase } \\
\text { [Candida parapsilosis] }\end{array}$ & 62.1 & 5.71 & 236 & 6 & 11 \\
\hline gi|354547939 & $\begin{array}{l}\text { protein CPAR2_404780, cell-wall agglutinin, N-terminal, li- } \\
\text { gand-sugar binding [Candida parapsilosis] }\end{array}$ & 114.0 & 3.80 & 96 & 3 & 4 \\
\hline gi|354547941 & $\begin{array}{l}\text { hypothetical protein CPAR2_404800, cell-wall agglutinin, N- } \\
\text {-terminal, ligand-sugar binding [Candida parapsilosis] }\end{array}$ & 144.0 & 4.19 & 118 & 4 & 3 \\
\hline gi|8927048 & elongation factor 2 [Candida parapsilosis] & 90.3 & 6.57 & 130 & 4 & 4 \\
\hline gi|354548043 & $\begin{array}{l}\text { hypothetical protein CPAR2_405810, similar to C. albicans } \\
\text { ACS1, putative acetyl-CoA synthetase[Candida parapsilosis] }\end{array}$ & 75.0 & 5.63 & 281 & 7 & 11 \\
\hline gi|354544776 & $\begin{array}{l}\text { hypothetical protein CPAR2_800530, similar to C. albicans } \\
\text { PCK1, phosphoenolpyruvate carboxykinase [Candida parap- } \\
\text { silosis] }\end{array}$ & 61.9 & 6.05 & 148 & 4 & 8 \\
\hline gi|354545113 & $\begin{array}{l}\text { hypothetical protein CPAR2_803890, similar to C. albicans } \\
\text { MLS1, malate synthase [Candida parapsilosis] }\end{array}$ & 62.7 & 8.73 & 396 & 23 & 14 \\
\hline gi|354546116 & $\begin{array}{l}\text { hypothetical protein CPAR2_204880, similar to C. albicans } \\
\text { PGI1, putative glucose-6-phosphate isomerase [Candida } \\
\text { parapsilosis] }\end{array}$ & 61.5 & 5.97 & 110 & 4 & 8 \\
\hline gi|354545980 & $\begin{array}{l}\text { hypothetical protein CPAR2 203520, similar to C. albicans } \\
\text { GND1, putative 6-phosphogluconate dehydrogenase [Candi- } \\
\text { da parapsilosis] }\end{array}$ & 55.4 & 5.94 & 270 & 6 & 8 \\
\hline gi|354546845 & $\begin{array}{l}\text { hypothetical protein CPAR2_212210, similar to C. albicans } \\
\text { ALD5, NAD-aldehyde dehydrogenase [Candida parapsilosis] }\end{array}$ & 54.0 & 5.71 & 671 & 17 & 38 \\
\hline gi|354545888 & $\begin{array}{l}\text { hypothetical protein CPAR2_202600, similar to C. albicans } \\
\text { TAL1, putative transaldolase [Candida parapsilosis] }\end{array}$ & 35.9 & 5.22 & 296 & 7 & 22 \\
\hline
\end{tabular}
were considered as useful for further procedure of protein purification. However, because the protein isolation with $\beta$-1,3-glucanase might result in slightly larger quantities of damaged cells as the deeper layer of the cell wall is affected (Klis et al., 2009), the milder protein isolation with $\beta-1,6-$ glucanase was further used, due to a reduced risk of potential contamination of the obtained extracts by cytoplasmic proteins derived from broken cells.

Moreover, fungal cells treated with heat or trypsin in order to deprive them of surface protein-dependent HPG- and HK-binding capacity (Bouchara et al., 1990), demonstrated a decrease in binding level to approximately $35-40 \%$ of the initial binding level, thus confirming a predominant role of the surface-located proteins, in comparison to other cell surface components, in the phenomenon of HPG and HK binding.

\section{The kinetic and thermodynamic studies on interactions between purified $C$. parapsilosis proteins and HPG or HK}

The next step was to isolate and purify particular HPG- or HK-binding C. parapsilosis cell wall proteins. Our purification strategy (see Materials and Methods section) required that a subset of candidate HPG- or HKbinding proteins be pre-determined. For that purpose, an affinity chromatography on agarose-immobilized HPG or HK was applied. As an example, a list of putative HPG-binding proteins is presented in Table 1; similar results were obtained for HK-coupled gel (data not

to the non-treated cells (Fig. 2). Therefore, these fractions 

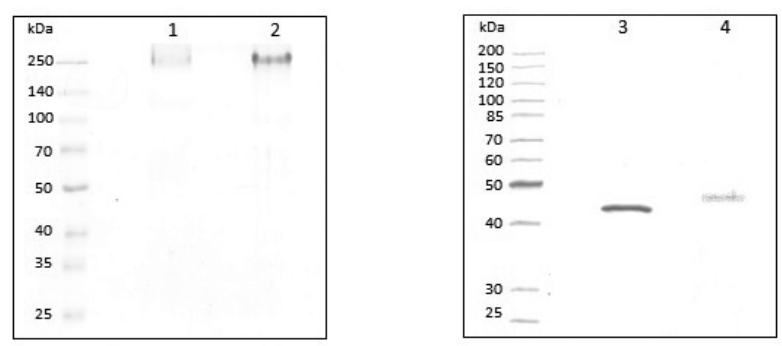

Figure 3. Electrophoretic characteristics of C. parapsilosis purified proteins: (1) CPAR2_404780, (2) CPAR2_404800, (3) Ssa2 and (4) Gnd1.

Purified C. parapsilosis proteins were separated by SDS-PAGE under reducing conditions in the Laemmli system using $10 \%(1,2)$ or $12 \%(3,4)$ separating gel and then stained with Coomassie Brilliant Blue R-250. A pattern for molecular-mass marker mixture is shown in the leftmost lane separately for each gel.

shown). Additionally, literature data on the involvement of particular C. parapsilosis proteins or their orthologs in the binding of various host proteins and peptides, such as histatin 5, HK, coagulation factor XII, plasma prekallikrein, fibronectin, vitronectin and laminin (López-Ribot et al., 1996; Karkowska-Kuleta et al., 2011; 2016; Kozik et al., 2015b; Seweryn et al., 2015) were taken into account.

Starting from the whole mixture of native, $\beta-1,6-$ glucanase-extractable fungal proteins, with the use of a combination of ion-exchange chromatography, gel filtration and chromatofocusing, we successfully isolated four HPG- and HK-binding proteins in SDS-PAGE pure forms (Fig. 3). These included two proteins similar to the Als family proteins (CPAR2_404780 and CPAR2_404800), heat shock protein Ssa2 and 6-phosphogluconate dehydrogenase (Gnd1). They also belong to two distinct groups of cell wall proteins distinguished above, thus ensuring a diverse look at the participation of these groups to the adhesion processes. An ability of these four C. parapsilosis purified proteins to directly compete with surface-located proteins for binding of $\mathrm{HK}$ or HPG was tested with a displacement assay using C. parapsilosis pseudohyphal forms (Fig. 4). Biotinylated human protein interacted at the same time with the surface of immobilized fungal cells and soluble individual purified protein in solution used at six-fold molar excess relative to HPG-Bt and HK-Bt. In the case of HK, presence of

Table 2. The kinetic and thermodynamic parameters for interactions between CPAR2 404780 , CPAR2_404800, Ssa2 and Gnd1 and HPG or HK, determined by SPR measurements. A simple Langmuir model (1:1) with a baseline drift was globally fitted to the sensograms presenting the interactions between a given fungal protein as a ligand and human proteins as an analyte. All the parameters are presented with the standard error (S.E.) indicating the confidence in the reported value for the particular parameter.

\begin{tabular}{llll}
\hline Protein & $K_{\mathrm{D}}(\mathrm{M})$ & $k_{\mathrm{a}}\left(\mathrm{M}^{-1} \mathrm{~s}^{-1}\right)$ & $k_{\mathrm{d}}\left(\mathrm{s}^{-1}\right)$ \\
\hline HPG binding & & & \\
\hline CPAR2_404780 & $3.57 \times 10^{-7} \pm 1.66 \times 10^{-8}$ & $5.09 \times 10^{4} \pm 4.21 \times 10^{3}$ & $1.82 \times 10^{-2} \pm 4.94 \times 10^{-4}$ \\
\hline CPAR2_404800 & $4.52 \times 10^{-7} \pm 1.61 \times 10^{-8}$ & $6.12 \times 10^{3} \pm 6.62 \times 10^{2}$ & $2.77 \times 10^{-3} \pm 2.60 \times 10^{-4}$ \\
\hline Ssa2 & $4.03 \times 10^{-7} \pm 1.91 \times 10^{-8}$ & $4.09 \times 10^{4} \pm 2.75 \times 10^{3}$ & $1.65 \times 10^{-2} \pm 2.71 \times 10^{-4}$ \\
\hline HK binding & & & \\
\hline CPAR2_404780 & $5.82 \times 10^{-9} \pm 1.14 \times 10^{-10}$ & $4.16 \times 10^{5} \pm 8.83 \times 10^{3}$ & $2.42 \times 10^{-3} \pm 6.97 \times 10^{-5}$ \\
\hdashline CPAR2_404800 & $6.27 \times 10^{-9} \pm 3.81 \times 10^{-10}$ & $1.77 \times 10^{6} \pm 1.17 \times 10^{5}$ & $1.11 \times 10^{-2} \pm 4.69 \times 10^{-4}$ \\
\hline Ssa2 & $6.93 \times 10^{-8} \pm 4.51 \times 10^{-9}$ & $1.31 \times 10^{5} \pm 2.76 \times 10^{4}$ & $9.08 \times 10^{-3} \pm 1.92 \times 10^{-4}$ \\
\hline Gnd1 & $7.22 \times 10^{-9} \pm 2.06 \times 10^{-10}$ & $4.89 \times 10^{5} \pm 3.99 \times 10^{4}$ & $3.53 \times 10^{-3} \pm 1.50 \times 10^{-4}$ \\
\hline
\end{tabular}

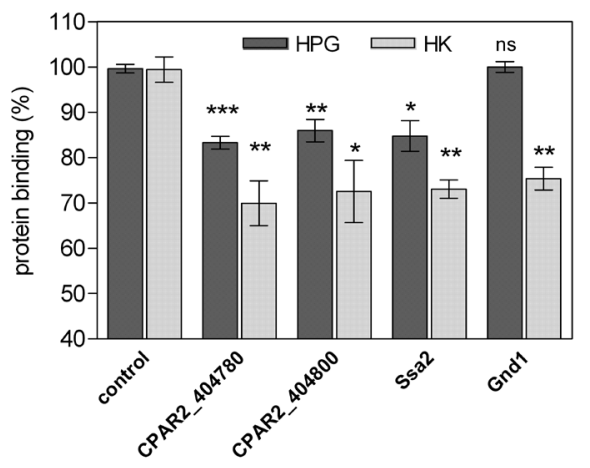

Figure 4. The displacement of HPG-Bt or HK-Bt by purified, soluble CPAR2_404780, CPAR2_404800, Ssa2 and Gnd1 from binding to C. parapsilosis pseudohyphae.

$40 \mu \mathrm{l}$ of $50 \mathrm{nM}$ solutions of HPG-Bt or HK-Bt were added to the microplate wells with $1 \times 10^{6}$ fungal cells grown as pseudohyphae for 24 hours at $37^{\circ} \mathrm{C}$ in RPMI 1640 medium, and mixed with $10 \mu \mathrm{l}$ of the solution of a particular soluble fungal protein: CPAR2_404780, CPAR2_404800, Ssa2 or Gnd1 prepared in 6-fold molar excess in PBS. After incubation for 1.5 hours at $37^{\circ} \mathrm{C}$ and washing out of the unbound proteins, the amount of bound biotinylated HPG or HK was determined with the SA-HRP/TMB detection system. The level of binding of the biotinylated protein to the fungal cells without competitor added was considered as $100 \%$. Bars on graph represent the mean values of 3 determinations \pm standard deviation. Statistical significance levels against the controls were determined for each human protein separately and are marked with ${ }^{*}$ for $p<0.05,{ }^{* *}$ for $p<0.01,{ }^{* * *}$ for $p<0.001$ and ns for "not significant".

all four purified proteins resulted in the decrease of $\mathrm{HK}$ binding level by about $25-30 \%$. Gnd1 was the only fungal protein that did not decrease the HPG binding level, suggesting that these two proteins did not interact with each other. However, the other three proteins caused a decrease in the HPG-binding level to approximately $85 \%$ of the initial level of HPG binding, as determined for the cells incubated with labeled human protein without any competitor added.

The SPR measurements were used to characterize, in kinetic and thermodynamic terms, the interactions of individual fungal protein-HPG or fungal protein-HK pairs. The sensograms for HPG and HK, confirming these interactions are shown in Fig. 5 and Fig. 6, respectively. As indicated in the Table $2, K_{\mathrm{D}}$ for both Als proteins CPAR2_404780 and CPAR2_404800 - were of an order of $10^{-7} \mathrm{M}$ when interacting with $\mathrm{HPG}$ or $10^{-9} \mathrm{M}$ when interacting with $\mathrm{HK}$, indicating that the binding affinity was higher for the Als protein$\mathrm{HK}$ interaction. Moreover, $K_{\mathrm{D}}$ determined for the interacting pair Ssa2-HK was by one order smaller $\left(10^{-8} \mathrm{M}\right)$ than that obtained for pair Ssa2-HPG $\left(10^{-7} \mathrm{M}\right)$. This observation again indicates a stronger interaction of the fungal protein with HK than with HPG. Interestingly, C. parapsilosis Gnd1 interacts only with $\mathrm{HK}$, giving a $K_{\mathrm{D}}$ value within a nanomolar range. No Gnd1 binding to HPG was observed with the SPR measurements. This also confirms the results described above, indicating the lack of direct competition of soluble 

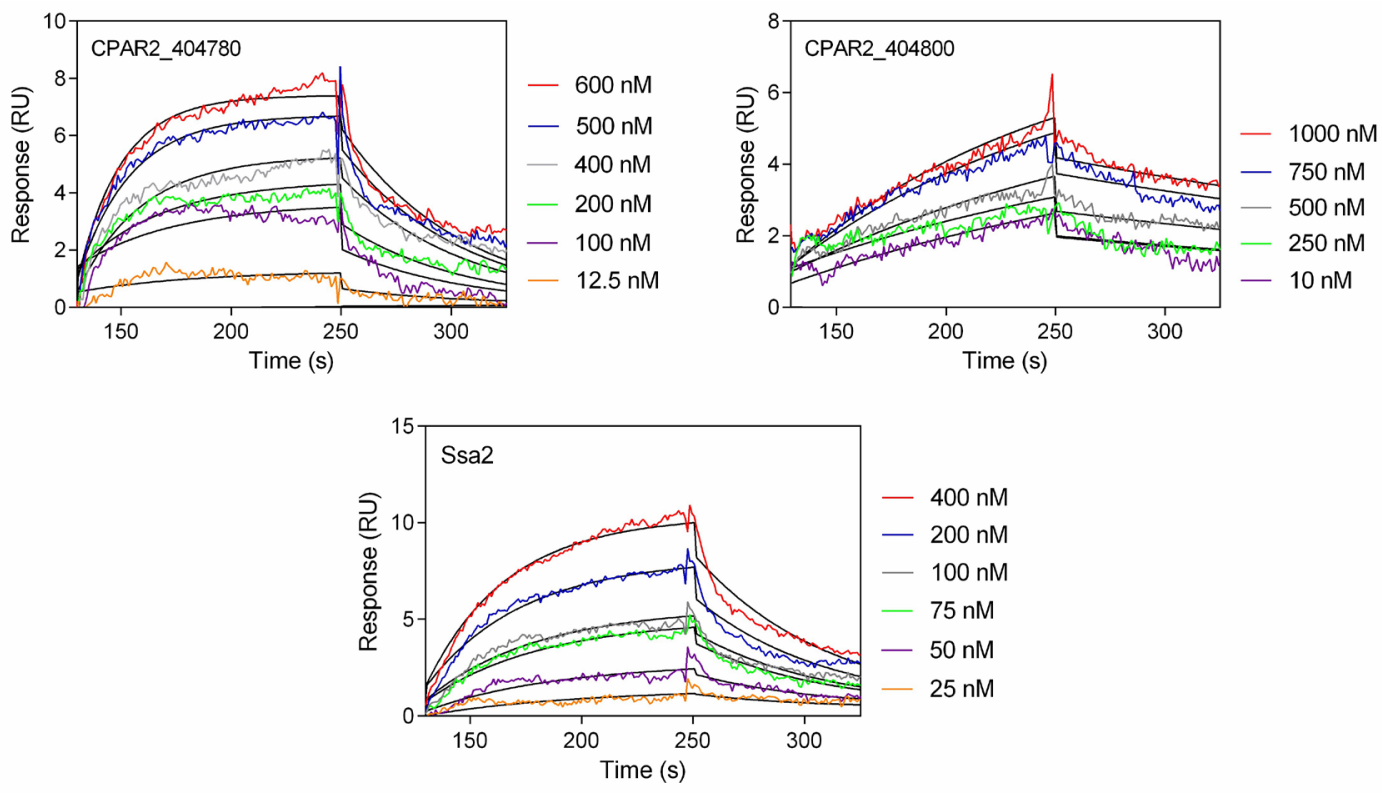

Figure 5. SPR sensograms representing interactions between HPG and CPAR2_404780, CPAR2_404800 and Ssa2.

SPR characteristics of the interaction between the HPG and a particular fungal protein immobilized onto a surface of the CM5 chip. The global data fits with the Langmuir 1:1 binding model (with a baseline drift) are shown as black lines. The HPG solutions at a concentration range of $10-1000 \mathrm{nM}$ were injected at a flow rate of $30 \mu \mathrm{l} / \mathrm{min}$ for 120 seconds.
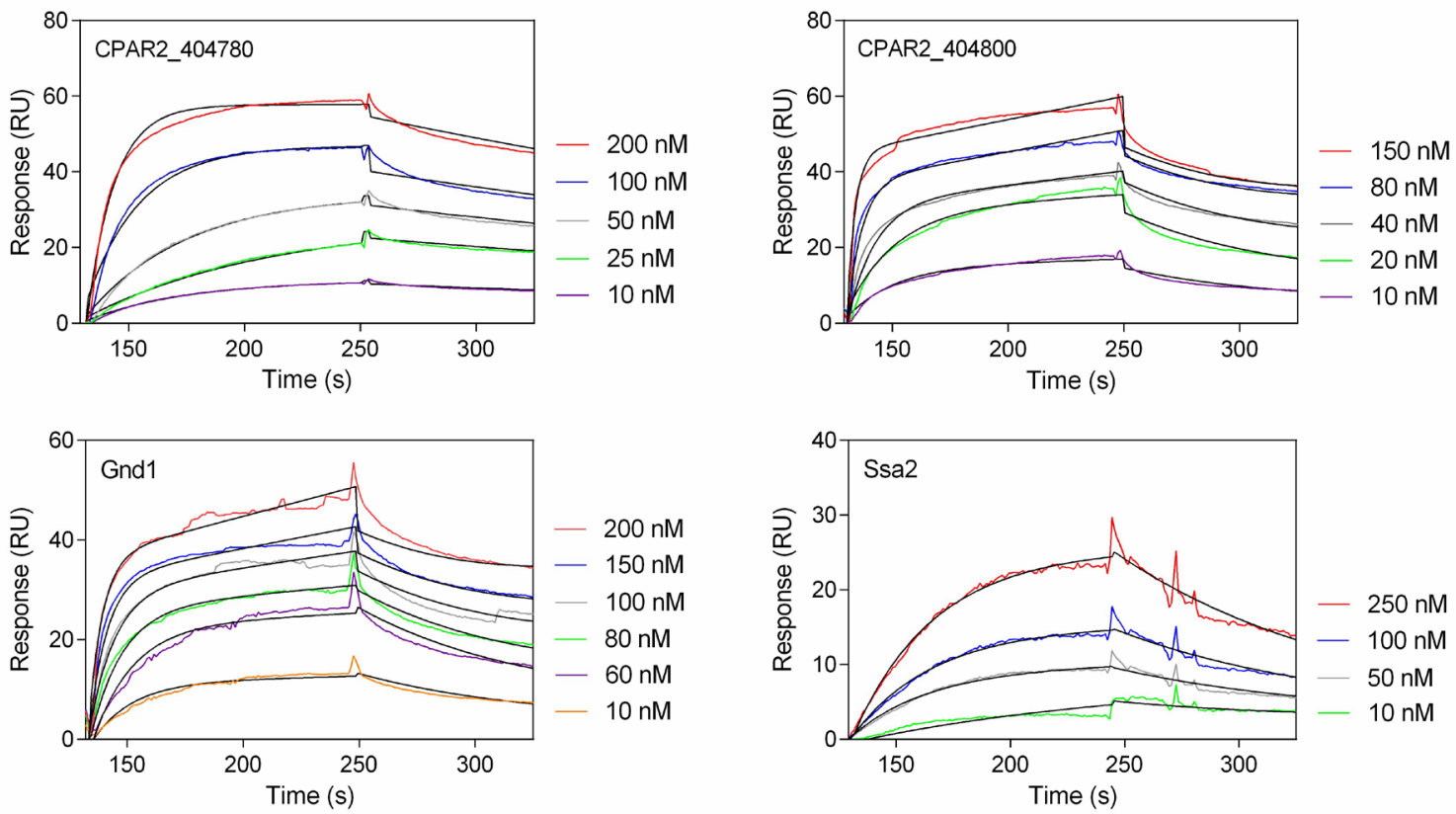

Figure 6. HK binding by CPAR2_404780, CPAR2_404800, Ssa2 and Gnd1 investigated by SPR measurements.

Interactions between HK and individual fungal protein presented as the entire sets of SPR sensograms obtained during the injection of HK solutions at a concentration range of $10-250 \mathrm{nM}$ at a flow rate of $30 \mu \mathrm{l} / \mathrm{min}$ for 120 seconds over the surface of the CM5 chip with immobilized C. parapsilosis individual protein. Black lines illustrate the global data fits with the Langmuir 1:1 binding model (with a baseline drift).

Gnd1 and surface-located proteins for binding to HPG (Fig. 4).

\section{DISCUSSION}

Invasive bacterial or fungal infections related to the dissemination of microbial cells with the bloodstream always carry a risk of uncontrolled activation of the human plasma proteolytic cascades involved in the maintenance of hemostatic balance (Degen et al., 2007; Oe- hmcke \& Herwald, 2010; Loof et al., 2014). Such complete deregulation of the fundamental processes of coagulation and fibrinolysis can lead to the development of systemic inflammatory response syndrome (SIRS), septic shock and severe sepsis associated with high morbidity and mortality rates Jacobi, 2002; Duggan et al., 2015; $\mathrm{Ng}$ et al., 2015). The process of sequestration of the key components of these systems, such as HPG and HK, at the pathogens' cell surface, often correlated with the acquisition of additional proteolytic activity, greatly fa- 
Table 3. The $K$ values (M) previously obtained for interactions between C. albicans (Seweryn et al., 2015) and C. tropicalis (Karkowska-Kuleta et al., 2016) cell wall-associated proteins and HK, as determined by SPR measurements (ND - not determined).

\begin{tabular}{lll}
\hline Protein name & C. albicans & C. tropicalis \\
\hline Agglutinin like sequence protein 3 & $2.13 \times 10^{-7}$ & $\mathrm{ND}$ \\
\hline Triosephosphate isomerase 1 & $7.87 \times 10^{-8}$ & $\mathrm{ND}$ \\
\hline Enolase 1 & $2.25 \times 10^{-7}$ & $1.42 \times 10^{-7}$ \\
\hdashline Phosphoglycerate mutase 1 & $4.79 \times 10^{-7}$ & $5.81 \times 10^{-7}$ \\
\hline Hyphally regulated protein & ND & $2.20 \times 10^{-7}$ \\
\hline
\end{tabular}

cilitates invasion of the host organism. Therefore, it has been currently extensively studied for pathogenic bacteria (Bhattacharya et al., 2012; Nickel \& Renné, 2012; Peetermans et al., 2016); however, for fungi from the Candida genus, important fungal pathogens for humans, this problem has not been sufficiently addressed. The results presented in this work suggest that such potential binding phenomenon might also result in the activation of the contact system or fibrinolytic system during the development of infections caused by C. parapsilosis.

There were reports concerning an ability of the cell wall proteins of C. albicans to bind host plasminogen (Funk et al., 2016) and several HPG-binding proteins were identified for this species, including atypical cell wall proteins phosphoglycerate mutase, glyceraldehyde-3-phosphate dehydrogenase, phosphoglycerate kinase, fructose bisphosphate aldolase, alcohol dehydrogenase, thioredoxin peroxidase, catalase and transcription elongation factor (Crowe et al., 2003; Poltermann et al., 2007), glycerol-3-phosphate dehydrogenase 2 (Luo et al., 2013) and pH-regulated antigen 1 (Luo et al., 2009). Moreover, it was suggested that binding of the C. albicans surface-associated enolase to HPG after its activation to plasmin might be beneficial for the pathogen during crossing of the layer of brain microvascular endothelial cells (Jong et al., 2003). Furthermore, in our previous studies carried out for $\mathrm{HK}$, not only the particular binding proteins were identified at $C$. albicans and C. tropicalis cell surface, but also the binding parameters were determined by SPR measurements performed for the interactions between this key component of the contact system and selected, purified C. albicans proteins (Table 3) (Seweryn et al., 2015; Karkowska-Kuleta et al., 2016).

However, in the case of C. parapsilosis, data on the interactions with these two plasma proteins are missing, especially if one takes into account the risk associated with the increasing frequency of invasive infections and candidemia caused by this species among neonates, patients with impaired immunity and critically ill individuals (Chatzinikolaou \& Raad, 2000; Pfaller et al., 2014; Wadile \& Bhate, 2015). It was only proven, so far, that HK could be adsorbed at the cell surface of C. parapsilosis pseudohyphal forms (Rapala-Kozik et al., 2008) and proinflammatory kinins might be generated from their precursors by C. parapsilosis secreted aspartic proteases (Bras et al., 2013). Therefore, in this work, for the first time, we characterized in details the interactions of $\mathrm{HPG} / \mathrm{HK}$ and the cell surface of C. parapsilosis pseudohyphae.

At first, the involvement of surface-exposed fungal proteins in the interactions with HPG and HK was confirmed (Fig. 2) and then four C. parapsilosis surface-associated proteins were purified. These proteins belonged to three diverse groups of cell wall proteins: (i) typical cell wall proteins, highly glycosylated adhesins covalently bound to the cell wall glucans, represented by CPAR2_404780 and CPAR2_404800 (Butler et al., 2009; Gacser, 2016), (ii) heat shock protein Ssa2, a chaperone putatively non-covalently associated with the cell wall although missing a signal peptide for classical secretion (López-Ribot et al., 1996), and (iii) an atypical cell wall-associated protein, Gnd1, a role of which at the fungal cell surface, as well its secretion pathway, have not been fully understood so far - it is primarily a cytoplasmic enzyme involved in the pentose phosphate pathway, but its confirmed presence at the microbe cell surface classifies it to an enigmatic group of "moonlighting proteins" (Karkowska-Kuleta \& Kozik, 2014).

In the case of $C$. albicans, the importance of Als proteins in the pathogenesis of infections was emphasized (Hoyer \& Cota, 2016), and that is why two C. parapsilosis proteins similar to $C$. albicans Als proteins were selected for further investigation of their involvement in the HPG- and HK-binding. Heat shock protein Ssa2, the surface-located chaperone involved in protein folding, was also reported to be responsible for binding of salivary antimicrobial peptide, histatin 5 (López-Ribot et al., 1996; Li et al., 2003; Sun et al., 2008). Gnd1, although an atypical cell wall protein, was reported to be a C. parapsilosis binding protein for extracellular matrix proteins, fibronectin and vitronectin (Kozik et al., 2015b). What is more, $C$. albicans Gnd1 was identified as a HK- and plasma prekallikrein-binding protein (Karkowska-Kuleta et al., 2011; Seweryn et al., 2015).

In the study presented here, the competition analyses had shown that all four investigated $C$. parapsilosis proteins might be responsible for attracting $\mathrm{HK}$ to the surface of pseudohyphae, and additionally three of them, excluding Gnd1, possess a HPG binding capacity. However, the incomplete displacement of binding of biotinylated human protein from binding to pseudohyphae by individual soluble fungal protein (Fig. 4) indicates a potential involvement of additional fungal proteins in these phenomena. Of the two human proteins investigated, HK bound more strongly to the tested fungal proteins, as judged by $K_{\mathrm{D}}$ values that were lower by one (for Ssa2) or two (for Als-like proteins) orders of magnitude than those determined for HPG under the same conditions. A comparison of the binding parameters, summarized in Table 3, that were previously obtained for $\mathrm{HK}$-binding proteins isolated from the cell walls of $C$. albicans and $C$. tropicalis, suggests that C. parapsilosis proteins studied in this work showed significantly stronger affinities to $\mathrm{HK}$. The proteins studied previously are both GPI-anchored cell wall proteins such as Als3 and Hyr, and atypical proteins: enolase, phosphoglycerate mutase and triosephosphate isomerase. Similarly to $C$. albicans, in the current research, C. parapsilosis Als proteins have been identified as strong HK-binders. For C. albicans and C. tropicalis, two HK-binding proteins were common for both species - enolase and phosphoglycerate mutase - whereas for C. parapsilosis two other proteins were characterized in terms of interactions with this particular human protein. Such observation of the differences between Candida species may be of great importance in the design of possible inhibitory agents. This is a particularly important issue in the case of premature newborns suffering from candidiasis. The involvement of surfaceexposed adhesins in the interactions with human epithelial cells can greatly increase the risk of Candida invasion and development of oral infections in children (Pammi et al., 2013). As C. parapsilosis is still considered as one of the most frequently isolated species from the Candida genus causing serious, life-threatening infections in neonates, investigating the role of adhesive, surface proteins of this species might be useful for prevention of such cases. 
In conclusion, the detailed kinetic and thermodynamic characterization of HPG and HK binding was performed for the first time for a set of four $C$. parapsilosis proteins including typical adhesins and atypical cell wall proteins. Such diversity of investigated HPG- and HK-binding proteins with regard to their functional and structural class indicates a high complexity of the mechanisms of interactions between the pathogen cell surface and the human host that can significantly hinder a full understanding of the processes that contribute to the pathogenicity of $C$. parapsilosis. Recently, an important role of CPAR2_404800 in the adhesion of C. parapsilosis to buccal epithelial cells and its involvement in the murine urinary candidiasis was reported (Bertini et al., 2016), demonstrating an urgent need to further investigate function of the surface proteins in the $C$. parapsilosis virulence mechanisms. Therefore, the detailed description of the adsorption phenomenon of these two important plasma proteins on the fungal cell surface sheds new light on molecular mechanisms of $C$. parapsilosis-dependent life-threatening invasive infections.

\section{Conflicts of interest}

The authors declare that there are no conflicts of interest.

\section{Acknowledgements}

This work was supported in part by the Jagiellonian University in Krakow (Statutory Funds of the Faculty of Biochemistry, Biophysics and Biotechnology BMN 29/2016 awarded to JKK). The Faculty of Biochemistry, Biophysics and Biotechnology of the Jagiellonian University in Krakow is a beneficiary of structural funds from the European Union (grant no. POIG.02.01.0012-064/08, "Molecular biotechnology for health") and a partner of the Leading National Research Center (KNOW) supported by the Ministry of Science and Higher Education, Poland.

\section{REFERENCES}

Benjamin DK Jr, Stoll BJ, Fanaroff AA, McDonald SA, Oh W et al. (2006) Neonatal candidiasis among extremely low birth weight infants: risk factors, mortality rates, and neurodevelopmental outcomes at 18 to 22 months. Pediatrics 117: 84-92

Bertini A, Zoppo M, Lombardi L, Rizzato C, De Carolis E, Vella A, Torelli R, Sanguinetti M, Tavanti A (2016) Targeted gene disruption in Candida parapsilosis demonstrates a role for CPAR2_404800 in adhesion to a biotic surface and in a murine model of ascending urinary tract infection. Virulence 7: 85-97. http://doi.org/10.1080/2 1505594.2015.1112491

Bhattacharya S, Ploplis VA, Castellino FJ (2012) Bacterial plasminogen receptors utilize host plasminogen system for effective invasion and dissemination. I Biomed Biotechnol 2012: 482096. http://doi. org/10.1155/2012/482096

Bonassoli LA, Bertoli M, Svidzinski TI (2005) High frequency of Candida parapsilosis on the hands of healthy hosts. J Hosp Infect 59: 159-162

Bouchara JP, Tronchin G, Annaix V, Robert R, Senet JM. (1990) Laminin receptors on Candida albicans germ tubes. Infect Immun 51: $48-54$

Bradford MM (1976) A rapid and sensitive method for the quantitation of microgram quantities of protein utilizing the principle of protein-dye binding. Anal Biochem 72: 248-254

Bras G, Bochenska O, Rapala-Kozik M, Guevara-Lora I, Faussner A, Kamysz W, Kozik A (2013) Release of biologically active kinin peptides, Met-Lys-bradykinin and Leu-Met-Lys-bradykinin from human kininogens by two major secreted aspartic proteases of Candida parapsilosis. Peptides 48: 114-123. http://doi.org/10.1016/j.peptides.2013.08.003

Butler G, Rasmussen MD, Lin MF, Santos MA, Sakthikumar S et al. (2009) Evolution of pathogenicity and sexual reproduction in eight Candida genomes. Nature 459: 657-662. http://doi.org/10.1038/nature08064
Castiblanco-Valencia MM, Fraga TR, Pagotto AH, Serrano SM, Abreu PA, Barbosa AS, Isaac L (2016) Plasmin cleaves fibrinogen and the human complement proteins $\mathrm{C} 3 \mathrm{~b}$ and $\mathrm{C} 5$ in the presence of Leptospira interrogans proteins: A new role of LigA and LigB in invasion and complement immune evasion. Immunobiology 221: 679-689. http://doi.org/10.1016/j.imbio.2016.01.001

Chatzinikolaou I, Raad II (2000) Intravascular catheter-related infections: a preventable challenge in the critically ill. Semin Respir Infect 15: $264-271$

Chow BD, Linden JR, Bliss JM (2012) Candida parapsilosis and the neonate: epidemiology, virulence and host defense in a unique patient setting. Expert Rev Anti Infect Ther 10: 935-946. http://doi. org/10.1586/eri.12.74

Crowe JD, Sievwright IK, Auld GC, Moore NR, Gow NA, Booth NA (2003) Candida albicans binds human plasminogen: identification of eight plasminogen-binding proteins. Mol Microbiol 47: 1637-1651

Degen JL, Bugge TH, Goguen JD (2007) Fibrin and fibrinolysis in infection and host defense. I Thromb Haemost 5: 24-31

Diekema DJ, Messer SA, Hollis RJ, Wenzel RP, Pfaller MA (1997) An outbreak of Candida parapsilosis prosthetic valve endocarditis. Diagn Microbiol Infect Dis 29: 147-153

Duggan S, Leonhardt I, Hünniger K, Kurzai O (2015) Host response to Candida albicans bloodstream infection and sepsis. Virulence 6: 316-326. http://doi.org/10.4161/21505594.2014.988096

Fathi N, Mohammadi R, Tabatabaiefar MA, Ghahri M, Sadrossadati SZ (2016) Sequence-identification of Candida species isolated from candidemia. Adv Biomed Res 5: 150. http://doi.org/10.4103/22779175.188485

Frick IM, Björck L, Herwald H (2007) The dual role of the contact system in bacterial infectious disease. Thromb Haemost 98: 497-502

Funk J, Schaarschmidt B, Slesiona S, Hallström T, Horn U, Brock M (2016) The glycolytic enzyme enolase represents a plasminogen-binding protein on the surface of a wide variety of medically important fungal species. Int J Med 306: 59-68. http://doi. org/10.1016/j.ijmm.2015.11.005

Gacser A (2016) Adhesins in Candida parapsilosis: Understudied players in virulence. Virulence 7: 65-67. http://doi.org/10.1080/21505594.2 015.1135288

Garzoni C, Nobre VA, Garbino J (2007) Candida parapsilosis endocarditis: a comparative review of the literature. Eur J Clin Microbiol Infect Dis 26: 915-926

Gogol M, Ostrowska D, Klaga K, Bochenska O, Wolak N, Aoki W, Ueda M, Kozik A, Rapala-Kozik M (2016) Inactivation of $\alpha 1$ proteinase inhibitor by Candida albicans aspartic proteases favors the epithelial and endothelial cell colonization in the presence of neutrophil extracellular traps. Acta Biochim Pol 63: 167-175. http://doi. org/10.18388/abp.2015_1163

Herwald H, Mörgelin M, Dahlbäck B, Björck L (2003) Interactions between surface proteins of Streptococcus pyogenes and coagulation factors modulate clotting of human plasma. J Thromb Haemost 1: 284-291

Holm K, Frick IM, Björck L, Rasmussen M (2011) Activation of the contact system at the surface of Fusobacterium necrophorum represents a possible virulence mechanism in Lemièrre's syndrome. Infect Immun 79: 3284-3290. http://doi.org/10.1128/IAI.05264-11

Hoyer LL, Cota E (2016) Candida albicans Agglutinin-Like Sequence (Als) Family Vignettes: A Review of Als Protein Structure and Function. Front Microbiol 7: 280. http://doi.org/10.3389/ fmicb.2016.00280

Huish S, Thelwell C, Longstaff C (2017) Activity Regulation by Fibrinogen and Fibrin of Streptokinase from Streptococcus Pyogenes. PLoS One 12: e0170936. http://doi.org/10.1371/journal.pone.0170936

Jacobi J (2002) Pathophysiology of sepsis. Am J Health Syst Pharm 59: S3-S8

Jong AY, Chen SH, Stins MF, Kim KS, Tuan TL, Huang SH (2003) Binding of Candida albicans enolase to plasmin(ogen) results in enhanced invasion of human brain microvascular endothelial cells. $J$ Med Microbiol 52: 615-622

Juyal D, Sharma M, Pal S, Rathaur VK, Sharma N (2013) Emergence of non-albicans Candida species in neonatal candidemia. $N A m I$ Med Sci 5: 541-545. http://doi.org/10.4103/1947-2714.118919

Kapteyn JC, Montijn RC, Dijkgraaf GJ, Van den Ende H, Klis FM (1995) Covalent association of beta-1,3-glucan with beta-1,6-glucosylated mannoproteins in cell walls of Candida albicans. J Bacteriol 177: 3788-3792

Kapteyn JC, Hoyer LL, Hecht JE, Müller WH, Andel A, Verkleij AJ, Makarow M, Van Den Ende H, Klis FM (2000) The cell wall architecture of Candida albicans wild-type cells and cell wall-defective mutants. Mol Microbiol 35: 601-611

Karkowska-Kuleta J, Kedracka-Krok S, Rapala-Kozik M, Kamysz W, Bielinska S, Karafova A, Kozik A (2011) Molecular determinants of the interaction between human high molecular weight kininogen and Candida albicans cell wall: Identification of kininogen-binding proteins on fungal cell wall and mapping the cell wall-binding regions on kininogen molecule. Peptides 32: 2488-2496. http://doi. org/10.1016/j.peptides.2011.10.021 
Karkowska-Kuleta J, Kozik A (2015) Cell wall proteome of pathogenic fungi. Acta Biochim Pol 62: 339-351. http://doi.org/10.18388/ abp.2015_1032

Karkowska-Kuleta J, Kozik A (2014) Moonlighting proteins as virulence factors of pathogenic fungi, parasitic protozoa and multicellular parasites. Mol Oral Microbiol 29: 270-283. http://doi. org/10.1111/omi.1207

Karkowska-Kuleta J, Kozik A, Rapala-Kozik M (2010) Binding and activation of the human plasma kinin-forming system on the cell walls of Candida albicans and Candida tropicalis. Biol Chem 391: 97-103. http://doi.org/10.1515/BC.2009.145

Karkowska-Kuleta J, Zajac D, Bochenska O, Kozik A (2015) Surfaceome of pathogenic yeasts, Candida parapsilosis and Candida tropicalis, revealed with the use of cell surface shaving method and shotgun proteomic approach. Acta Biochim Pol 62: 807-819. http://doi. org/10.18388/abp.2015_1140

Karkowska-Kuleta J, Zajac D, Bras G, Bochenska O, Seweryn K, Kedracka-Krok S, Jankowska U, Rapala-Kozik M, Kozik A (2016) Characterization of the interactions between human high-molecularmass kininogen and cell wall proteins of pathogenic yeasts Candida tropicalis. Acta Biochim Pol 63: 427-436. http://doi.org/10.18388/ abp.2016_1353

Klis FM, Sosinska GJ, de Groot PW, Brul S (2009) Covalently linked cell wall proteins of Candida albicans and their role in fitness and virulence. FEMS Yeast Res 9: 1013-1028. http://doi.org/10.1111/ j.1567-1364.2009.00541.x

Kozik A, Gogol M, Bochenska O, Karkowska-Kuleta J, Wolak N, Kamysz W, Aoki W, Ueda M, Faussner A, Rapala-Kozik M (2015a) Kinin release from human kininogen by 10 aspartic proteases produced by pathogenic yeast Candida albicans. BMC Microbiol 15: 60 . http:/ /doi.org/10.1186/s12866-015-0394-8

Kozik A, Karkowska-Kuleta J, Zajac D, Bochenska O, Kedracka-Krok S, Jankowska U, Rapala-Kozik M (2015b) Fibronectin-, vitronectinand laminin-binding proteins at the cell walls of Candida parapsilosis and Candida tropicalis pathogenic yeasts. BMC Microbiol 15: 197. http://doi.org/10.1186/s12866-015-0531-4

Laemmli UK (1970) Cleavage of structural proteins during the assembly of the head of bacteriophage T4.Nature 227: 680-685

Li XS, Reddy MS, Baev D, Edgerton M (2003) Candida albicans Ssa1/2p is the cell envelope binding protein for human salivary histatin $5 . \mathrm{J}$ Biol Chem 278: 28553-28561

Long AT, Kenne E, Jung R, Fuchs TA, Renné T (2016) Contact system revisited: an interface between inflammation, coagulation, and innate immunity. J Thromb Haemost 14: 427-437. http://doi. org/10.1111/jth. 13235

Loof TG, Deicke C, Medina E (2014) The role of coagulation/fibrinolysis during Streptococcus pyogenes infection. Front Cell Infect Microbiol. 4: 128. http://doi.org/10.3389/fcimb.2014.00128

López-Ribot JL, Alloush HM, Masten BJ, Chaffin WL (1996) Evidence for presence in the cell wall of Candida albicans of a protein related to the hsp70 family. Infect Immun 64: 3333-3340

Lovero G, De Giglio O, Montagna O, Diella G, Divenuto F, Lopuzzo M, Rutigliano S, Laforgia N, Caggiano G, Montagna MT (2016) Epidemiology of candidemia in neonatal intensive care units: a persistent public health problem. Ann Ig 28: 282-287. http://doi. org/10.7416/ai.2016.2107

Luo S, Hoffmann R, Skerka C, Zipfel PF (2013) Glycerol-3-phosphate dehydrogenase 2 is a novel factor $\mathrm{H}$-, factor $\mathrm{H}$-like protein 1-, and plasminogen-binding surface protein of Candida albicans. I Infect Dis 207: 594-603. http://doi.org/10.1093/infdis/jis718

Luo S, Poltermann S, Kunert A, Rupp S, Zipfel PF (2009) Immune evasion of the human pathogenic yeast Candida albicans: Pra1 is a Factor H, FHL-1 and plasminogen binding surface protein. Mol Immunol 47: 541-550. http://doi.org/10.1016/j.molimm.2009.07.017

Lupetti A, Tavanti A, Davini P, Ghelardi E, Corsini V, Merusi I, Boldrini A, Campa M, Senesi S (2002) Horizontal transmission of Candida parapsilosis candidemia in a neonatal intensive care unit. J Clin Microbiol 40: 2363-2369

Maeda H, Yamamoto T (1996) Pathogenic mechanisms induced by microbial proteases in microbial infections. Biol Chem Hoppe Seyler 377: 217-226

Marín E, Parra-Giraldo CM, Hernández-Haro C, Hernáez ML, Nombela C, Monteoliva L, Gil C (2015) Candida albicans Shaving to Profile Human Serum Proteins on Hyphal Surface. Front Microbiol 6: 1343. http://doi.org/10.3389/fmicb.2015.01343

Ng K, Schorr C, Reboli AC, Zanotti S, Tsigrelis C (2015) Incidence and mortality of sepsis, severe sepsis, and septic shock in intensive care unit patients with candidemia. Infect Dis (Lond) 47: 584-587. http://doi.org/10.3109/23744235.2015.1028100

Nickel KF, Renné T (2012) Crosstalk of the plasma contact system with bacteria. Thromb Res 130: S78-S83. http://doi.org/10.1016/j. thromres.2012.08.284

Núñez-Beltrán A, López-Romero E, Cuéllar-Cruz M (2017) Identification of proteins involved in the adhesion of Candida species to different medical devices. Microb Pathog 107: 293-303. http://doi. org/10.1016/j.micpath.2017.04.009
Oehmcke S, Herwald H (2010) Contact system activation in severe infectious diseases. J Mol Med (Berl) 88: 121-126

Pammi M, Holland L, Butler G, Gacser A, Bliss JM (2013) Candida parapsilosis is a significant neonatal pathogen: a systematic review and meta-analysis. Pediatr Infect Dis J 32: e206-e216. http://doi. org/10.1097/INF.0b013e3182863a1c

Peetermans M, Vanassche T, Liesenborghs L, Lijnen RH, Verhamme P (2016) Bacterial pathogens activate plasminogen to breach tissue barriers and escape from innate immunity. Crit Rev Microbiol 42: 866-882. http://doi.org/10.3109/1040841X.2015.1080214

Pfaller MA, Andes DR, Diekema DJ, Horn DL, Reboli AC, Rotstein C, Franks B, Azie NE (2014) Epidemiology and outcomes of invasive candidiasis due to non-albicans species of Candida in 2,496 patients: data from the Prospective Antifungal Therapy (PATH) registry 2004-2008. PLoS One 9: e101510. http://doi.org/10.1371/ journal.pone.0101510

Poltermann S, Kunert A, von der Heide M, Eck R, Hartmann A, Zipfel PF (2007) Gpm1p is a factor H-, FHL-1-, and plasminogenbinding surface protein of Candida albicans. J Biol Chem 282: $37537-$ 37544

Pongrácz J, Benedek K, Juhász E, Iván M, Kristóf K (2016) In vitro biofilm production of Candida bloodstream isolates: any association with clinical characteristics? J Med Microbiol 65: 272-277. http://doi. org/10.1099/jmm.0.000207

Potempa J, Banbula A, Travis J (2000) Role of bacterial proteinases in matrix destruction and modulation of host responses. Periodontol 2000 24: 153-192

Rapala-Kozik M, Bras G, Chruscicka B, Karkowska-Kuleta J, Sroka A, Herwald H, Nguyen KA, Eick S, Potempa J, Kozik A (2011) Adsorption of components of the plasma kinin-forming system on the surface of Porphyromonas gingivalis involves gingipains as the major docking platforms. Infect Immun 79: 797-805. http://doi. org/10.1128/IAI.00966-10

Rapala-Kozik M, Karkowska J, Jacher A, Golda A, Barbasz A, Guevara-Lora I, Kozik A (2008) Kininogen adsorption to the cell surface of Candida spp. Int Immunopharmacol 8: 237-241. http://doi. org/10.1016/j.intimp.2007.07.005

Sabino R, Sampaio P, Carneiro C, Rosado L, Pais C (2011) Isolates from hospital environments are the most virulent of the Candida parapsilosis complex. BMC Microbiol 11: 180. http://doi. org/10.1186/1471-2180-11-180

Sanchez V, Vazquez JA, Barth-Jones D, Dembry L, Sobel JD, Zervos MJ (1993) Nosocomial acquisition of Candida parapsilosis: an epidemiologic study. Am J Med 94: 577-582

Seweryn K, Karkowska-Kuleta J, Wolak N, Bochenska O, KedrackaKrok S, Kozik A, Rapala-Kozik M (2015) Kinetic and thermodynamic characterization of the interactions between the components of human plasma kinin-forming system and isolated and purified cell wall proteins of Candida albicans. Acta Biochim Pol 62: 825-835. http://doi.org/10.18388/abp.2015_1142

Shannon O, Herwald H, Oehmcke S (2013) Modulation of the coagulation system during severe streptococcal disease. Curr Top Microbiol Immunol 368: 189-205. http://doi.org/10.1007/82_2012_283

Smeesters PR, McMillan DJ, Sriprakash KS (2010) The streptococcal M protein: a highly versatile molecule. Trends Microbiol 18: 275-282. http://doi.org/10.1016/j.tim.2010.02.007

Sun H (2006) The interaction between pathogens and the host coagulation system. Physiology (Bethesda) 21: 281-288. http://doi. org/10.1152/physiol.00059.200

Sun JN, Li W, Jang WS, Nayyar N, Sutton MD, Edgerton M (2008) Uptake of the antifungal cationic peptide Histatin 5 by Candida albicans Ssa2p requires binding to non-conventional sites within the ATPase domain. Mol Microbiol 70: 1246-1260

Trofa D, Gácser A, Nosanchuk JD (2008) Candida parapsilosis, an Emerging Fungal Pathogen. Clin Microbiol Rev 21: 606-625. http:// doi.org/10.1128/CMR.00013-0

Vieira ML, Naudin C, Mörgelin M, Romero EC, Nascimento AL, Herwald H (2016) Modulation of Hemostatic and Inflammatory Responses by Leptospira Spp. PLoS Negl Trop Dis 10: e0004713. http:// doi.org/10.1371/journal.pntd.0004713

Wadile RG, Bhate VM (2015) Study of clinical spectrum and risk factors of neonatal candidemia. Indian J Pathol Microbiol 58: 472-474. http://doi.org/10.4103/0377-4929.168888

Wollein Waldetoft K, Svensson L, Mörgelin M, Olin AI, Nitsche-Schmitz DP, Björck L, Frick IM (2012) Streptococcal surface proteins activate the contact system and control its antibacterial activity. J Biol Chem 287: 25010-25018. http://doi.org/10.1074/jbc. M112.373217

Yang YL, Leaw SN, Wang AH, Chen HT, Cheng WT, Lo HJ (2011) Characterization of yeasts colonizing in healthy individuals. Med Mycol 49: 103-106. http://doi.org/10.3109/13693786.2010.487076

Yılmaz Karadağ F, Ergen P, Aydın Ö, Doğru A, Tanıdır B, Vahaboğlu MH (2016) Evaluation of epidemiological characteristics and risk factors affecting mortality in patients with candidemia. Turk J Med Sci 46: 1724-1728. http://doi.org/10.3906/sag-1505-70 